\title{
THE FEDERAL RESERVE BANK
} of ST. LOUIS

\section{Monetary and Exchange Rate Policy in Austria: An Early Example of Policy Coordination}

\author{
John A. Tatom \\ Heinz Gluck \\ Dieter Proske
}

Working Paper 1992-005A

http://research.stlouisfed.org/wp/1992/92-005.pdf

PUBLISHED: Economic Policy Coordination in an Integrating Europe,

Bank of Finland, 1992.

\author{
FEDERAL RESERVE BANK OF ST. LOUIS \\ Research Division \\ 411 Locust Street \\ St. Louis, MO 63102
}

\begin{abstract}
The views expressed are those of the individual authors and do not necessarily reflect official positions of the Federal Reserve Bank of St. Louis, the Federal Reserve System, or the Board of Governors.

Federal Reserve Bank of St. Louis Working Papers are preliminary materials circulated to stimulate discussion and critical comment. References in publications to Federal Reserve Bank of St. Louis Working Papers (other than an acknowledgment that the writer has had access to unpublished material) should be cleared with the author or authors.
\end{abstract}

Photo courtesy of The Gateway Arch, St. Louis, MO. www.gatewayarch.com 


\author{
MONETARY AND EXCHANGE RATE POLICY IN AUSTRIA: \\ AN EARLY EXAMPLE OF POLICY COORDINATION \\ Heinz Glück, \\ Dieter Proske \\ and \\ John A. Tatom*
}

$92-005 A$

\begin{abstract}
Austrian National Bank
P. 0. Box 61

A-1011 Vienna, Austria
\end{abstract}

Federal Reserve Bank

P. O. Box 442

St. Louis, MO 63166

Comments are welcome.

* Austrian National Bank and Federal Reserve Bank of St. Louis, respectively. We gratefully acknowledge the comments of Clemens J.M. Kool and Albert Jäger on earlier drafts of this paper.

The views expressed in this paper are those of the authors and not necessarily of the institutions with which they are affiliated.

This paper is subject to revision and is for review and comment. Not to be quoted without the authors' permission. 
MONETARY AND EXCHANGE RATE POLICY IN AUSTRIA:

AN EARLY EXAMPLE OF POLICY COORDINATION

\begin{abstract}
:
This paper describes the evolution of Austrian exchange rate and monetary policy as an example of the benefits of policy coordination and credibility. This policy improved the performance of the Central Bank in achieving its twin objective of stabilizing the internal and external value of the currency. In this process, policymakers have sought to exploit the advantages of credibility by building a reputation for sticking to their policy. The evidence presented exhibits the increased coordination between Austrian and German nominal aggregates in the course of time. These accomplishments have apparently not required tying the real performance of the Austrian economy to any adverse permanent real consequences of German monetary policy, in particular, to its inflation-unemployment trade off.
\end{abstract}

\title{
KEYWORDS
}

Policy coordination, monetary policy, exchange rate policy, credibility, causality tests, cointegration, convergence.

JEL CLASSIFICATION:

E31, E52, E58, F15, F31, F32, F33 


\title{
MONETARY AND EXCHANGE RATE POLICY IN AUSTRIA: \\ AN EARLY EXAMPLE OF POLICY COORDINATION
}

\author{
Heinz GLÜCK - Dieter PROSKE - \\ John A. TATOM
}

\section{Introduction}

The evolution of Austrian exchange rate and monetary policy illustrates the benefits of policy coordination and credibility ${ }^{1}$ ). The emergence of Austria's hard currency policy followed from policymakers' recognition of the benefits from coordination of economic policy with other countries, especially with Germany. The importance of making credible both the feasibility of this policy and Austria's commitment to it emerged very soon.

Austria is a small open economy with high capital mobility; its exchange rate policy currently pegs its currency to that of a lowinflation anchor currency, i.e. the Deutsche mark. Since the breakdown of the Bretton woods Agreement, twenty years ago, however, there have been two distinct periods or regimes for Austrian monetary and exchange rate policies:

i) In the 1970s, exchange rate policy was discussed in terms of price stabilization, the ability to import stability, and the role of the real appreciation of the schilling in this process. A limited float against each currency aimed at pursuing the domestic inflation goal. Monetary measures were more discretionary during this period.

ii) At the end of the 1970s and in the 1980s, the necessary harmonization of fundamentals between the anchor country and Austria was emphasized; the idea of stabilizing expectations

1) Kahn (1987) provides a useful description of the benefits and tho rnats of nollev coordination. 
also became central to policy discussions. Since then, Austria's monetary policy has been characterized as a 'hard currency option'.

Policy developments in the recent period can be viewed as attempts to achieve policy coordination and to foster the credibility and reputation of the monetary authorities. A growing literature points to the significant role of credibility and reputation in economic policy in individual countries, and these issues also bear great importance in the context of the European Monetary System and the European Monetary Union. Thus, the focus of discussion in Austria has also shifted to these issues. The credibility of Austria's exchange rate policy was widely achieved at the beginning of the 1980s, but challenges to this credibility, or to Austria's commitment to its policy, have occurred subsequently and are inevitable in the future. Such challenges have clarified the real economic significance of credibility and reputation and strenghtened the understanding of their role in the successful implementation of the hard currency policy.

The evolution of the Austrian exchange rate policy has been presented elsewhere (Handler 1989, Hochreiter and Knöbl 1991, and others), so only a short historical outline is presented-in the next section. Then we examine some evidence on the effects of changes in Austrian policy coordination.

\section{The Evolution of the Hard Currency Policy}

When the Bretton Woods System came to an end and the United States closed the gold window in August 1971, Austria had to reconsider the anchor for its exchange rate and monetary policy. A free float was not seriously considered because of the supposed uncertainties connected with $1 t$, and especially the impact of these uncertainties on contracts. It was widely believed that these uncertainties would permanently lower economic activity and make it more volatile. As a result, Austria was one of the first 
countries to monitor an effective exchange rate and to use it as an 'indicator' for policy.

The indicator comprised the currencies of nine important trading partners (German mark, Swiss franc, Dutch guilder, Belgian franc, Swedish, Norwegian and Danish krona, Lira and Pound Sterling). These were not exactly the most important trading partners. The French franc, for instance, was not included, nor was the dollar. The nine cumencies were weighted into a basket according to their trade weights (only trade in goods was taken into account, not trade in services or capital transactions).

The adoption of such a basket as an indicator for policy was based on Austria's National Bank Act which defines price stability as the primary task and responsibility of the Austrian National Bank. Article 3 of paragraph 2 explicitly says that the Bank "...has to ensure with all the means at its disposal that the value of the Austrian currency is maintained with regard both to its domestic purchasing power and to its relationship with stable foreign currencies." 2 )

Following the breakdown of the Bretton Woods Agreement this task was interpreted as requiring that the value of the schilling be stabilized relative to currencies with relatively stable domestic prices, that is, currencies whose external value had been rising relative to other countries with higher inflation rates. This was expected to keep the rise of Austrian import prices relatively low. In a small open economy with a high import content in production and consumption, with a fast pass-through of world market prices to domestic prices, which, in turn, are passed through to wages and costs, such a policy is expected to restrain the domestic price level to a correspondingly high extent. Thus, the currencies of those countries that, under floating, had inflated their economies (i.e., the Pound Sterling and the Lira) or that were devalued for reasons of competitiveness (Swedish

2) This dual stability objective is only consistent if the value of the schilling is pegged to currencies which enjoy a stable purchasing power. The subsequent evolution of exchange rate policy can perhaps best be understood in terms of these twin -2:..1:.... 
Krona) were eliminated from the basket in the course of the following years.

In 1973, Austria unilaterally declared its adherence to the European snake, though not becoming an official member of this arrangement. Thus, between this time and 1976 there were two parallel guidelines, the snake and the indicator, but they never seriously conflicted. However, the observed depreciation of other snake currencies against the German mark implied, given attempts to stabilize the indicator, a concomitant weakening of the schilling against the Deutsche mark, as long as the snake's fluctuation limits $(+/-21 / 4 \%)$ were adhered to. This problem was resolved first by doubling the band acceptable to Austria and then by dropping the snake orientation altogether and pegging the schilling exclusively to the German mark.

This change in the orientation of the exchange rate regime was also a consequence of another related Austrian innovation, the role of real appreciations in the 'hard currency policy'. In 1974, inflation had surged world-wide in the wake of the first oil price shock. In Austria the rate of inflation approached 10 percent. Because of the pass-through effects that were inherent in the Austrian system of social partnership, the schilling was revalued by $41 / 2$ percent to bring inflation down.

It was clear that this hard currency policy would result in a real appreciation and in a worsening of the current account. Both effects, however, were accepted by the policymakers as they were confident that the domestic economy would adjust to the new exchange rate level in due course. There was also the conviction that an alternative exchange rate policy that focused on competitiveness or employment would not succeed because wage earners would react to devaluation-induced price increases and a 'vicious circle' would result. Experience in 'soft currency' countries had made this very clear (Hochreiter - Knobbl 1991):

Thus, three considerations were decisive for the development of the hard currency policy. First, price stabllity can be imported via the pass-through from the prices of imported goods to consumer 
prices or to the prices of production inputs. In some periods even real appreciations were accepted despite adverse effects on the current account. Second, appreciations cause a profit squeeze in the exposed sector that leads to rationalization, innovation, rising productivity, and improved structure. It also prevents excessive wage increases. Third, by these mechanisms - a lower inflation rate as a precondition for the incomes policy and a profit squeeze in the exposed sector limiting the possibilities for wage increases - some 'virtuous circle' effects are brought into play, validating the appreciated exchange rate in the longer run.

\section{Stabilizing Expectations}

At the beginning of the 1980s, the Austrian economy faced a series of national and international problems which had effects similar to those of a negative supply shock. Again, the option of devaluation was not chosen - on the one hand because of the long held conviction that this would not produce lasting positive effects, but also because the credibility of the hard currency policy already had to be defended.

The authorities also recognized that in a world of high and rising capital mobility a devaluation would raise the variability of exchange rates and that this effect would alter the public's expectations about future exchange rates. Once a devaluation was effected - and reputation lost - these expectations would change. More volatile capital flows and movements in the interest rate differential could result. Policymakers believed that an important role of the central bank was to stabilize the market participants' expectations by reducing, as much as possible, the uncertainties about the future exchange rate.

In the short term, this is done by limiting exchange rate fluctuations to an absolute minimum through the permanent presence of the Bank in the foreign exchange market and by the adjustment of interest rates. Austrian exchange market intervention goes 
beyond the scope of conventional intervention. For example, it encompasses measures to coordinate the timing of the federal government's capital imports with intervention policy (see, for instance, Tichy 1986).

In the long run, however, stabilization of exchange rate expectations can only be achieved if underlying macroeconomic aggregates, or economic fundamentals, are also stabilized. Thus, economic policy had to be coordinated with. Germany if the feasibility of the hard currency option was to become and remain credible. In this respect, successful economic policy coordination was a precondition for credibility.

'Monopolistic Coordination'

The modern focus on international policy coordination was initiated by Hamada (1976), and has largely been promoted by discussions such as the 'Group of 'Three (Five, Seven)' meetings about cooperation in macroeconomic policymaking and the analyses of the costs and benefits of joining the European Monetary System. The principal issue concerns the question of externalities in the choice of macroeconomic policies by individual governments due to international spill-over effects. A coordinated policy internalizes these externalities by maximizing a weighted sum of the governments' objectives.

Concern for these externalities was preeminent following the breakdown of Bretton Woods and was central to the adoption of the exchange rate management system in the 1970 s and to early support for the snake arrangement. In Austria, the volatility of the foreign exchange market and the uncertainties related to it were reduced, and the advantages of fixed exchange rates regained, to a degree, by the evolution of close coordination with German monetary policy. Such coordination, in effect, extends reputational advantages (or disadvantages) of the Bundesbank to Austrian policy so long as the Austrian and German policy is credible. This policy also leads to an asymmetric convergence of 
fundamentals, as Austrian economic developments and policy adjust to innovations in German policy or fundamentals, but German policy and fundamental developments are independent of Austrian innovations. In effect, the German Bundesbank independently chooses its monetary policy, while Austria - taking into account its institutional and market-oriented peculiarities - 'ties its hands' on exchange rate policy and adjusts its monetary policy to international developments, transmitted essentially from the anchor currency country.

A constellation like this has been labelled 'monopolistic coordination' (Spahn 1991) and is characterised, first, by the hegemonic position of the leading currency which is fully acknowledged by the following country. Second, this type of policy coordination can be reached without an institutional process of joint decision-making in economic policy. The basic agreement is possible because this constellation is in accordance with the interests of the partners. Austria imports monetary stability and reputation, while Germany need not take care of any adverse monetary influences coming in the opposite direction, though they should be small in view of Austria's size. Another advantage that has been shown to be valid for EMS-countries (Giavazzi and Pagano 1988) may also apply to Austria, namely that it was able to 'export' its responsibility for restrictive policies to Frankfurt, by attributing the consequences of restrictive policy to the Bundesbank.

Monopolistic coordination finds its justification in its stabilizing function. As Spahn (1991) argues: "Every monetary production economy needs an institution providing an anchor of stability for prices and price expectations. In a closed economy this job is - and should be - done by the central bank. In an open system one country has to take over the stabilising function. We should bear in mind that the Bretton-Woods system finally broke down precisely because countries with a stable monetary system were forced to import inflationary pressures from abroad."3)

3) Belongia and Chrystal (1990) discuss some of the disadvantages of exchange rate targeting. They focus particular attention to the costs of a real exchange rate shock associated with setting

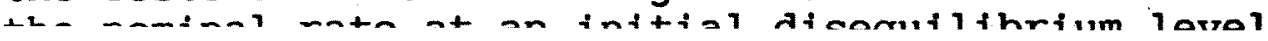


Monetary Policy

The development of the hard currency policy required alterations of monetary policy. Generally speaking, the room for manoeuvre for monetary policy was reduced and subordinated under the exchange rate target.

From the breakdown of Bretton woods until 1979, monetary policy tried to keep nominal long-term interest rates stable while pursuing the exchange rate objective for the indicator. The domestic interest rate level, it was believed, should be protected as far as possible from exogenous influences in order to stabilize it as a cost factor. No balance of payments problems were expected to result because of foreign exchange restrictions, market segmentation and investors' preferences (see Winckler 1977 and Glück 1977).

This interest rate component of policy was maintained until 1979 , when it could no longer be defended against a sharp rise in international interest rates. After one-third of Austria's international reserves was lost, interest rate policy was redesigned from its domestic orientation towards an instrument supporting the exchange rate target. This change also reflected the view that the weakening of financial market segmentation due to liberalisation and globalisation of world capital markets, meant that domestic interest rates would have to become more closely linked to international interest rates. In Austria's case, given the exchange rate regime, this link was more narrowly to Germany, so the differential between Austrian and German rates became a target for the exchange rate policy. Especially the short-term interest rate is to be considered as an intermediate target which is controlled by means of direct interest rate policy (key interest rates, open market interest rates) or liquidity policy measures (use of the domestic or foreign source components of money supply creation). 
The Loss of Monetary Autonomy

The constraint on monetary policy that is imposed by a fixed nominal exchange rate and free capital movements can be illustrated by a simple (monetary) model of exchange rate determination (see, for example, Branson 1991 and Dornbusch 1980).

In the monetary approach to price determination domestic prices are a function of domestic nominal money supply and real money demand. With real money demand depending on real income and the nominal interest rate the price equation reads as follows:

(1) $p=m-a y+b i-x$,

where:

$m=$ logarithm of the nominal stock of domestic money

$\mathrm{p}=$ logarithm of the domestic price level

$y=$ logarithm of the real GDP

$i$ = domestic interest rate

$\mathbf{x}=$ represents any other factor that shifts portfolio preferences

$a$ = income elasticity of the demand for money

$b=$ semi-elasticity of the demand for real money balances with respect to the interest rate.

The same relationship holds for the anchor country:

(2) $\mathrm{p}^{*}=\mathrm{m}^{*}-a y^{*}+b i^{*}-\mathrm{x}^{*}$

where coefficients $a$ and $b$ are assumed to be equal for both countries. With open goods markets and similar consumption baskets across countries, the domestic price level is tied to the center's by

(3) $p=e+p *$,

(purchasing power parity) 
e denoting the logarithm of the price of the home currency in terms of the anchor currency.

This equation can be considered as goods market arbitrage condition. (It holds less strictly, of course, the larger the share of non-traded goods.)

Under the assumption of purchasing power parity, equations (1) and (2) can be combined to an equation for the exchange rate of these two countries:

(4) $e=\left(m-m^{*}\right)-a\left(y-y^{*}\right)+b\left(i-i^{*}\right)-\left(x-x^{*}\right)$.

The model establishes that relative changes in money supply, interest rate and real income affect the exchange rate. An increase in the money supply at home leads to an equiproportionate depreciation. Because an increase in domestic real income raises the demand for real balances and thus leads to a fall in domestic prices it induces an offsetting exchange rate appreciation. Relatively higher domestic interest rates, by contrast, reduce the demand for real balances, raise prices, and therefore bring about an exchange depreciation.

With free capital movements, the domestic interest rate is tied to the center's by the financial market arbitrage condition

(5) $i=i^{*}+\Delta e^{\prime}+r p$,

where $\Delta e^{\prime}$ is the expected change of the exchange rate and $r p$ is the risk premium.

With a nominal exchange rate peg and sufficient credibility of this policy, $\Delta e^{\prime}$ would be zero.

Combining equations (4) and (5) and solving for $m$, the constraint on domestic monetary policy is:

(6) $m=e+m^{*}+a\left(y-y^{*}\right)-b\left(\Delta e^{\prime}+r p\right)+\left(x-x^{*}\right)$ 
With e fixed, $\Delta e^{\prime}$ is zero; given that $\mathrm{rp}$, which is minimized when $e$ is fixed, as well as $x$ and $x *$ are constants, the following first-difference ( 1 ) relationship holds:

(7) $\Delta \mathrm{m}=\Delta \mathrm{m} *+\mathrm{a}_{1}\left(\Delta \mathrm{Y}-\Delta \mathrm{Y}^{*}\right)$

Domestic nominal money growth is therefore determined by the anchor country's money supply growth and the real economic growth differential between these two countries. As a result, inflation rates and nominal interest rates are also closely tied together when $e$ is fixed by the domestic monetary authority. In such an economy, the central bank is restricted to influence only the sources of money creation, i.e. domestic or foreign component, but not its magnitude.

Credibility and Reputation

Issues of credibility and reputation and their benefits have been central to the transformation of exchange rate and monetary policy in Austria over the past 20 years 4 ).

Credibility refers to the extent to which beliefs concerning a certain policy conform to official announcements about this policy. To achieve credibility, the authorities must precommit themselves to a particular policy rule. Credibility may thus also be viewed as a measure of the degree to which policymakers tie their hands on future policies to their public policy announcements. Reputation, on the other hand, is the probability which the public assigns to the consistent pursuit of a certain policy. It is derived by learning over time from the actual behavior of the monetary authorities (Weber 1991).

4) The role of credibility and reputation was first modeled by Kydland and Prescott (1977) and further developed by Barro and Gordon (1983). The distinguishing feature of this work is that government is not exogenous in the analysis. Policy is made endogenous by specifying a government objective function and assuming that the government maximizes its objective under the constraints imposed by private equilibrium behavior (Persson 
In order to obtain credibility, two elements are needed: First, an economic program must be feasible, stand the test of professional scrutiny, and reflect the experience of, and lessons from, other episodes. Second, policy commitments must not be susceptible to the time inconsistency problem, providing incentives to change the policy direction in mid-course. Policymakers must demonstrate that they are willing to continue an announced policy. For example, the adoption of a rule-based policy framework can reduce discretion and the perception of arbitrariness and, thereby, strengthen confidence in the policy-making process (Calvo and Frenkel 1991).

In the beginning, the hard currency policy was not widely perceived to be feasible (see Hochreiter and Winckler 1991 for more detail). The measures taken in 1974 were followed by a massive deterioration of the current account deficit which reached 4,4 8 of GDP in 1977. The strategy became increasingly criticized and confidence that it could be maintained was low. Industry opposed this policy and favoured a real exchange rate rule instead of pegging to the German mark. There was also criticism in academic circles and international organisations.

In this period, however, the central bank did not leave any doubt that it would maintain its exchange rate objectives, and if necessary, intervene and adjust the interest rate differential to whatever level required. Key policymakers had come to the conclusion that it was the economy which had to adjust to the exchange rate and not the other way around. A deviation from the course would leave central bank, budget, and unions worse off.

Later, in October 1978, in order to placate critics of the policy a realignment in the snake was handled in such a way that the schilling lost about 1 \& against the German mark. Obviously, this: change was inconsistent, so that credibility and reputation were damaged.

In 1979, however, when oil prices rose quickly in the wake of th: Iranian revolution, the idea of appreciating the nominal exchanoc rate to keep inflationary pressures low was again brought into 
discussion, and in september of that year the schilling was revalued against the German mark by $11 / 2$ percent, followed by gradual appreciations until late 1981 amounting finally to $41 / 2$ percent. Since then, the schilling/mark relation remained nearly constant.

Subsequently, credibility and also reputation were rebuilt. Official and press statements increasingly supported the policy. Also industry finally dropped its opposition. Thus, the public attached increasingly high probability to the consistent pursuit of the announced policy. The argument which nowadays is often used in connection with the EMS, that by a policy of this kind a country is enabled to borrow anti-inflationary reputation from the Bundesbank by credibly fixing the exchange rate to the German mark, was first adopted, credibly maintained and validated in the Austrian case.

Measuring Credibility

The credibility of a currency peg is often measured by the interest rate differential. A low interest rate is usually considered as the reward for a successful buildup of credibility. If the pegging country achieves better fundamentals, interest rates can even be lower than in the anchor country. This will, however, be the exceptional case. Usually the country pegging to a stable anchor currency has a positive risk premium, or interest rates are in general a bit higher than those of the reference currency. In Austria the 'necessary' interest rate differential to Germany was considered to be up to one percentage point in the early eighties, but has decreased in the wake of ever increasing capital mobility and rising credibility of Austrian exchange rate policy.

When credibility is endangered the interest rate differential may temporarily rise considerably, however. This was the experience of the Netherlands: In March 1983 an unexpected, though small, devaluation of the Dutch guilder against the Deutsche mark led to 
a remarkable change in market sentiment. Interest rates, which had been about three-quarters of a percentage point below German rates in the first quarter of the year, rose to about one percentage point above German rates after the devaluation. It took quite a long time until confidence was restored sufficiently to allow interest rate differentials to return to pre-devaluation levels. The Dutch central bank has interpreted this as an indication for the need to evaluate each policy measure more carefully with regard to its effects on credibility.

Similarily, Virén (1989) finds little sensitivity of interest rates in Finland, Iceland and Norway to interest rates abroad in his study on interest rates, capital movements and monetary autonomy in the EFTA countries. He concludes that relatively high domestic interest rates in these countries do not indicate a lack of capital mobility, but rather the problems these countries have experienced in terms of the credibility of the official exchange rate policy rule5).

In Austria, credibility of exchange rate policies might have suffered between 1984 and 1987 because of a surge in domestic inflation, a deterioration in the current account and a negative growth differential. Just as in the Dutch case the rise in the interest rate differential can be considered as an indicator of this credibility loss6).

The inflation rate (as measured by the change in the consumer price index) surged in Austria in 1984 (chart 1) to a large part because of an increase in the value added tax (VAT) and a considerable rise in administered prices. In 1984, the 5,6 percent Austrian inflation rate was about 2 points higher than a year earlier and about 3 points higher than in Germany; Austrian

5 ) There may be imperfect substitutability of these assets due to tax treatment, tax or other sources of sovereign risk which mediate against this interpretation, however. Kool and Tatom (1988) provide evidence that short-term interest rates are not closely correlated across G-5 countries in the 1977-87 period. Nevertheless, long-term rates are significantly linked, so that, if real rates are arbitraged across countries, then long-run inflation rares are expected to be similar as well.

6) This view is not generally held in Austria but it makes sense chan vanitur at tho dato 
inflation (and interest rates) remained high relative to Germany until the second half of 19887). Episodes like this should reinforce or enhance credibility, although it is premature to assert that this really also occurred. Nevertheless, this example of a temporary widening in the interest rate spread suggests that it is a useful measure of credibility.

\section{Empirical Evidence on Convergence and Coordination}

The alterations in Austrian policy coordination since 1970 suggest that there should be evidence of convergence between Austrian and German economic developments, especially for nominal aggregates. The outcome for growth of output, current account, fiscal deficits, and unemployment may not be so clear on a priori grounds. Some casual evidence of convergence can be obtained by examining the data in Table 1 . More direct evidence based on causality tests also is provided below.

Since the early 1970s, Austria succeeded in reducing its inflation rate by more than the reduction in Germany; generally, however, its inflation has been higher than in Germany. Chart 1 shows the rate of increase of consumer prices and the levels of nominal short and long-term interest rates. The chart also suggests that inflation and interest rates have exhibited some tendency to converge in the 1980s. Another nominal measure, unit labor costs in manufacturing, is a widely used measure for price performance and competitiveness because it largely excludes the sheltered sector. This measure also shows a tendency to converge (see table 1) because faster growth in Austrian productivity has offset faster wage growth in Austria.

According to table 1, there also has been some convergence in the growth rate of real GDP since the early 1970s, although this has been associated with slower growth for Austria. Austria's external

7) A withholding tax on interest receipts was introduced at the same time and kept in force until mid-1986. But the tax rate was too low ( $71 / 2$ of in 1984 and $5 \%$ thereafter) to fully exnlain the rise in the interest differential. 
position moved toward balance over the three periods shown in the table, but it has consistently been in deficit compared with Germany's persistent surpluses. Moreover, both the direction of movement in the middle period and the relative size of the movement toward surplus in the last period diverge in the two countries.

The fiscal deficits shown in table 1 have not exhibited convergence; the fiscal deficit worsened in the early and late1980s in Austria, but worsened by a smaller amount in Germany in the early 1980s and improved in the late 1980s. Since 1989, of course, the German deficit has moved up (to 2,1 percent of GDP in 1991 ) while that in Austria has declined (to 3,3 percent in 1991), so that the two have converged to a degree. Finally the unemployment rate in the two countries, like real GDP growth, has moved in the same direction in each period, but the rise, especially in the early 1980s, has been smaller in Austria than in Germany. This relative success is typically attributed to Austria's specific policy mix, occasionally referred to as "Austrokeynesianism".

Generally speaking, the convergence of economic fundamentals with those of the center country has been realised to a relatively high extent. In Austria's case, the disciplinary effects of coordination to Germany were earned, but this fact did not entail tying every aspect of the real economy to the German one. The experience suggests that pegging the exchange rate does not necessarily imply that, for instance, the inflation-unemployment trade-off of the anchor country had to be fully accepted - at least not in the longer run, when the structural characteristics of the labor markets (comparatively high real wage flexibility ir: Austria) dominate (Hochreiter - Knöbl 1991). Also, a much less favourable current account balance was sustained in Austria over. long period. 
Some Evidence on Coordination

Economic theory indicates that monetary authorities can only achieve an exchange rate objective by surrendering other objectives of monetary policy. For example, the independent use of monetary policy to achieve a domestic inflation objective requires that the exchange rate be free to reflect monetary developments abroad. Thus, in the first of the three distinct Austrian monetary regimes identified above, the Bretton-Woods period, Austrian monetary aggregates, price level and other nominal measures were determined by the committment to maintain a fixed price of the U.S.Dollar and other currencies. In the second regime, limited floating was allowed against each currency with the aim of pursuing a domestic inflation goal. During this period (from the breakdown of the Bretton Woods agreement (III/1971) to the breakdown of the limited-floating regime), monetary measures were more discretionary. Finally, since III/1979 Austrian monetary policy has been characterized as a "hard currency option" and has been narrowly focused on efforts to fix the DM/AS exchange rate. During this period, Austrian monetary and other nominal measures should be determined by German economic developments.

To test whether these characterizations are supported by the data, Granger causality tests are conducted for each period for the relationship between Austrian and German money stocks (M1 and M3), consumer prices, industrial production, and interest rates. If the coordination hypotheses above are correct, then in the latest period (III/1979 to IV/1989), German money, prices and interest rates should cause, in a Granger sense, their Austrian counterparts and, due to the asymmetry of the coordination, the Austria measures should have no influence on German developments 8 ). That is, causality should be unidirectional. If German

8) The period ends in 1989 to avoid the distortionary influence of the temporary abandonment of the price stability goal by the Bundesbank when they implemented a fixed convertibility peg to the East German Mark as part of the unification process. As a result, there was a monetary shock to West Germany and countries pegging to the DM as the adjustment to this transition progressed. While the results described here should not be altered by these developments in any qualitative way,.

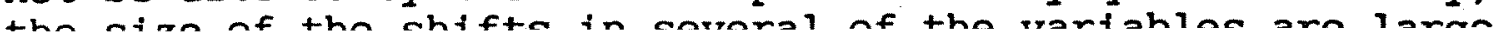


monetary policy becomes more causally significant for Austrian nominal developments and if monetary factors play a major role in the German cyclical experience, the cyclical experience of the two countries should also become more closely linked. To test this linkage, each country's industrial production growth is also examined.

During the previous period (III/1971 to II/1979), Austrian economic developments are expected to be less systematically influenced by developments abroad. In particular, since both Austria and Germany had floating rates between themselves and other countries, there is no a priori reason for a causal relation in either direction for the nominal variables. Finally, in the earliest period for which data are available (generally I/1960 to II/1971), both Germany and Austria were participants in the Bretton Woods arrangements, so that their domestic nominal economic measures were related to a degree; in this period Granger causality could arise and in either direction.

The Granger causality test was conducted for each variable in each period using the same procedure. First, the univariate time series process of the growth rate (first-difference in the logarithm) was determined for the Austrian and German measure, then up to eight quarterly lagged values of the counterpart variable for the other country were tested to determine if the past behavior of the measure in Germany (Austria) had statistically significant explanatory power for the same variable in Austria (Germany)9). A five percent significance level is used as the test criterion. For interest rates, simple first-differences of the variables are

enough so that this brief experience could bias the results. 9 ) The Q-statistics reported in tables 2 to 7 are Box-Pierce statistics to test for white-noise residuals with 12 lags. None of these statistics are statistically significant, indicating that the residuals for the test equations are white-noise. The test equations were also estimated using first-order moving average error processes. There is some evidence that MAl error processes are significant for industrial production and German long-term interest rates when they substitute for autoregressive processes that are otherwise significant. The autoregressive processes used below fit the data better for the univariate and causality test equations than when the MA terms are included and insignificant AR terms are deleted. In addition, no causality test result is altered when MA terms are - . 
used. First-differences ( 1 ) are used because all of the measures are nonstationary. The numbers in parantheses in table 2 to 8 are computed as t-statistics.

Money stock (M1)

Table 2 gives the causality tests for money stock (M1) growth in each country. The M1 data are not seasonally adjusted, so seasonal dummies are included for the first (S1), second (S2) and third quarters (S3). The same test was conducted without the seasonal dummy variables and the results were identical. In the first period, Austrian M1 growth (M1A) is AR2, but there is evidence of causality by German M1 growth over the previous two quarters. This causality is unidirectional, as no lag of Austrian M1 growth significantly influences German $M 1$ growth. During the second period, M1 growth is independent in each country, as hypothesized. During the latest period of coordination, there is also evidence of unidirectional causality from German M1 growth to Austrian MI growth.

Monetary Aggregate M3

Table 3 presents similar results for M3 growth. During the initial period, no evidence was found for causality for M3 growth in one country by M3 growth in the other. The closest result to statistical significance is when one lag of German M3 growth is added to the reported Austrian equation; in this case, the $t-$ statistic for this term is 1.80 , which is not significant at a 5 percent level. In the second period, there is again no causality from German M3 growth to Austrian M3 growth, but the test yields evidence of causality from Austrian M3 growth. This result is unexpected and is not consistent with the other results for this period. In the final period, German M3 growth causes Austrian M3 growth and reverse causality is rejected. The latter supports the coordination hypothesis 10 ).

10) Causality tests for monetary base measures reveal an absence of causality in all three periods (the first begins in 1962 
Consumer Prices

Table 4 presents causality results for the consumer price index. These results are somewhat more mixed than for the other variables. In particular, in the first period, when both country's inflation rates are expected to depend more on reserve currency growth outside the two countries, there is some evidence of causality from Austrian inflation to German inflation. This result is dubious, however, because it only arises with an unusually long pure time delay of 4 to 6 quarters. In the second period, there is causality from the German rate of price increase to that in Austria. In the coordination period, the results again show that German developments play a causal role in Austria, but Austrian nominal developments, like inflation, do not cause their German counterpart.

\section{Industrial Production}

Table 5 shows the causality results for the growth rate of industrial production in each country. In all three periods the growth of German industrial production causes growth of industrial production in Austria. Only in the last period is there any evidence of causality from Austrian industrial production growth to German industrial production growth. This may not reflect any influence of the exchange rate regime, however, because the overall effect is zero (the sum of the lagged growth rates equals $0.2750, t=0.92)$. Nevertheless the evidence is consistent with a tightening in the relationship between the real sectors of the two economy.

noise, except for the German base in the coordination period, which is AR1. This absence of causality, given the results for M1 and M3, suggests that the existing measures of the base are inadequate for capturing monetary policy actions. For example, neither measure includes excess reserves. Also, unusual movements in the currency ratio affect the base associated with a given level of the money stock. For this reason, the targeting and measurement of the monetary base was abandoned targeting and Measur 
Long-term Interest Rates

Table 6 shows the causality results for long-term interest rates. Only the 1971-79 and 1979-89 periods are reported because of data availability. The quarterly average of monthly bond yields on 10year government bonds are used for each country. During the limited-floating rate period, long rates show unidirectional causality from Germany and Austria, while there is bidirectional causality in the 1980s. The former result, like the CPI results above for 1971-79, suggests that monetary authorities in Austria were influenced by external developments in Germany, despite the limited floating that took place. The causality from German to Austrian long rates in the 1980s is insensitive to whether three lags, only the significant third lag, or no lags of the change in the Austrian rate are included. The bidirectional causality for long rates in the coordination period is not typical of the other results, but it suggests that adjustments in financial markets are not as asymmetric for long rates under such coordination11).

Short-terms Interest Rates

The results for short-term rates in table 7 are more consistent with the hypotheses. The short-term rate in Austria and Germany are the quarterly averages of monthly interest rates on 3-month government securities. During the latest period, the hypothesis of unidirectional causality from Germany to Austria is not rejected. During the limited-floating period, changes in short-term rates in each country are independent of changes in short-term rates in the other country. Finally, in the earliest period, there is unidirectional causality from Germany to Austria; this may reflect

11) Note that the equation for the German long rate in the 1980s indicate a negative effect of Austrian rates on German rates. When the two past Austrian changes are constrained to have no total effect on the German rate, however, the constraint cannot be rejected $(t=-1.09)$. The constrained effect is $-0.6787(t=-2.54)$ in the first quarter and 0.6787 in the next quarter. Thus, the curious suggested causality from

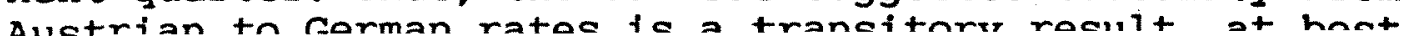


the dominance of the larger German economy in inducing real economic changes in Austria under fixed exchange rates 12 ).

Cointegration of Short-term Interest Rates

The strong, close connection between German and Austrian shortterm interest rates since 1979 and its attribution to Austrian economic policy actions is supported by the causality results. Stronger evidence of this relation is found in cointegration tests 13$)$. For the coordination period, the cointegration vector is:

(8) ISAt $=\frac{1.7145}{(5.92)}+\underset{(20.79)}{0.8256}$ ISGt + Rt

$$
\mathrm{R}^{2}=0.913 \quad \text { S.E. }=0.6522 \quad \text { D.W. }=1.07
$$

The residual, $R_{t}$, is stationary according to the Dickey-Fuller test recommended by Engle and Granger (1987). In particular,

(9) $\Delta R_{t}=-\frac{0.5394 R t-1}{(-3.82)}$

and no lags of the dependent varaible are significant. The $t-$ statistic is much larger in absolute value than the critical value ( 5 percent) of 3.37 given in Engle and Granger, table 214).

Such a strong long-run relationship between these short rates does not hold in either of the earlier periods, even though the same

12) In the fixed rate period, only the fifth lag of the change in the German rate is statistically significant and only when it is included alone instead of along with the first four lags. When the causality test is conducted with no lagged dependent variables, Austrian rates still have no statistically significant effect on German rates.

13) If variables are cointegrated, then causality tests involving their first-differences can be biased against rejecting the absence of causality by omitting a significant lagged residual from the cointegrating vector from the causality test equation. In both of the causality equations for Austrian short-rates and for Austrian inflation such a consideration has no effect on the reported causality test results.

14) The reverse cointegrating vector yields the same statistically significant evidence of cointegration in the coordination period of the $1980 \mathrm{~s}$ and not in the other two periods. 
unidirectional causality from German to Austrian rates holds in the fixed rate period. In the floating rate period, ISG is not significant in the cointegrating vector $(t=1.88)$; moreover, the $t$-statistic on the lagged residual in testing its stationarity is only - 2.79, which is small enough in absolute value to reject stationarity.

In the fixed rate period, the cointegrating vector is:

$$
\begin{aligned}
\text { (10) ISA } & =\frac{-0.7837+0.5897}{(-1.22)} \text { ISG } \\
R^{2} & =0.319 \quad \text { S.E. }=2.2802 \quad \text { D.W. }=0.181
\end{aligned}
$$

and the stationarity test results are:

$$
\begin{aligned}
& \text { (11) } \Delta \mathrm{R}_{t}=-0.0773 \mathrm{Rt}-1 \\
& (-1.20) \\
& R^{2}=0.03 \quad \text { S.E. }=0.9554 \quad \text { D.W. }=2.10 \quad Q(12)=9.08 \\
& \text { (12) } \Delta R_{t}=\frac{-0.1161 R_{t-1}+\underset{(-1.78)}{0.3929}(2.57)}{(2.5 t-4} \\
& R^{2}=0.149 \quad \text { S.E. }=0.9382 \quad \text { D.W. }=2.03 \quad Q(11)=4.18
\end{aligned}
$$

In both cases stationarity of the residual, and hence cointegration, are rejected.

Since arbitrage should tie expected real rates of return across countries together, expected inflation should also be cointegrated when nominal rates are. A check of the time series properties of consumer prices in Austria and Germany over the three regime periods indicates that they are $I(2)$ in all three periods. Inflation is cointegrated in at least the second and third periods, however 15$)$. The cointegrating vectors and residual tests

15) The augmented Dickey-Fuller test for cointegration indicates that the levels of consumer prices in Germany and Austria are cointegrated in only the last period, III/1979 to II/1991. This result is marginal, however, and only marginally better than in the first period. In particular, in the latest period the $t$-statistic on the lagged residual (when a significant fourth and elght lagged dependent variable are included) is -3.23 , only slightly larger in absolute value than the critical value of -3.17 , or the -3.16 value obtained for the -. 
for each of the three periods are given in table 8 . The coefficient on German inflation in the first period is not statistically significant at a 5 percent level, although it is close ( 6.7 percent). In the subsequent periods, the coefficient on German inflation is statistically significant and the residual is stationary, according to the significant $t$-values on the lagged residuals in the respective cointegration tests. Thus, inflation in Germany and Austria are cointegrated, at least since the breakdown of the Bretton Woods agreement. It is not surprising, then, that nominal interest rates have been cointegrated since 1979; indeed, it is more surprising that these interest rates were not cointegrated earlier.

\section{Summary}

The evidence presented in this section is strongly supportive of the hypotheses above, especially the coordination hypotheses. Money growth, inflation, industrial production growth and shortterm interest rates all exhibit strong unidirectional causality from Germany to Austria in the 1980s. There is causality in long rates too, but it appears to be bidirectional. In the previous floating rate period, short-term rates, and monetary growth for both M1 and M3 are independent in each country, as would be expected with floating rates and independent monetary policies. Consumer prices show bidirectional causality during this period, however, but this may reflect the relative importance of common external price shocks on both countries. Finally, in the first period when policy in each country was constrained to a fixed exchange rate regime, the results are mixed. M3 growth in each country shows complete independence from the other, but M1 growth and short-term interest rate changes show uniderectional causality from Germany to Austria, while inflation shows a peculiar reversal of this unidirectional causality. 
IV. Conclusions

Austrian monetary and exchange rate policy have evolved quite successfully into a coordinated policy that has improved the performance of the Central Bank in achieving its twin objectives of stabilizing the internal and external value of the currency. In this process, policymakers have sought to exploit the advantages of credibility by building a reputation for sticking to their policy. The evidence presented suggests they have succeeded. These accomplishments have not been without a few major departures that temporarily cost reputation, however.

Austrian coordination is one-sided or monopolistic by choice, but also by necessity. A more discretionary Austrian exchange rate policy would have created only minor external costs abroad, so that foreign policymakers would have had little incentive to forceably impose or negotiate a coordinated policy with Austria. On the other hand, the relative importance of international trade to Austria and its commitment to price stability require that foreign externalities be minimized. The movement from the Bretton woods arrangement, which, in principle at least, provided a degree of trade, exchange rate and domestic price stability until it broke down, through the limited floating regime to the current hard currency policy offers interesting contrasts in efforts to secure the Central Bank goals and their outcomes.

The discussion and evidence show that by passively coordinating domestic monetary policy to German monetary policy decisions through the active enforcement of the fixed exchange rate, Austria has successfully tied its nominal economic performance - its inflation rate, interest rates and nominal income growth - to Germany's. These outcomes were the deliberate cholce of policymakers who saw these nominal outcomes to be superior to the alternatives available through other policies and who recognized the independent benefits for the economy of building (by importing) credibility and reputation for committment to the hard currency policy. These accomplishments have apparently not required tying the real performance of the Austrian economy to any 
adverse permanent real consequences of German monetary policy, in particular, to its inflation-unemployment trade off.

The principal risk of Austrian-style coordination, which now has spread to several other countries, is that the center country will temporarily abandon its commitment to price stability. In this event, like the breakdown of Bretton Woods, the small open economies would unexpectedly and passively confront the same implicit c:cice. The twin goals of stabilizing the external and internal value of the currency will not be met without finding a new anchor. The unprecedented pressures on German monetary authorities created by unification and their response to it suggest that such concerns are easily overstated.

Periodic challenges to nolicymakers' commitments, like those examined in the paper, show that temporary departures from policy commitments can have relatively high real costs to the economy. Because such departures have reputational effects, these costs persist. Thus, the case for stability in policy rules, even in the face of perceived short-term inefficiencies in these policies, appears, from the Austrian perspective, to be as strong, or stronger, than proponents of the critical role of reputation have suggested. 


\section{REFERENCES}

BARRO, R. and GORDON, D. (1983): Rules, discretion, and reputation in a model of monetary policy. Journal of Monetary Economics 12, pp. 101-121.

BELONGIA, M.T. and CHRYSTAL, A.(1990): The Pitfalls of Exchange Rate Targeting: A Case Study from the United Kingdom. Federal Reserve Bank of St. Louis Review 72, September/October, pp. 15-24.

BRANSON, W. (1991): Exchange Rate Policies for the EFTA Countries in the 1990s. EFTA Occasional Paper 35, Geneva.

CALVO, G. and FRENKEL, J. (1991): Credit Markets, Credibility, and Economic Transformation. Journal of Economic Perspectives 5, pp. 139-148.

DORNBUSCH, R. (1980): Exchange Rate Economics: Where Do We Stand? Brookings Papers on Economic Activity, 1:1980, pp. 143-205.

DORNBUSCH, R. (1988): The European Monetary System, the Dollar and the Yen. In: GIAVAzzI, F., MICossI, S. and MILLER, M. (eds.): The European Monetary System. Cambridge University Press, pp. 23-41.

ENGLE, R.F. and GRANGER, C.W.J. (1987): Co-Integration and Error Correction: Representation, Estimation, and Testing. Econometrica 55, pp. 251-276.

GIAVAZZI, F. and PAGANO, M. (1988): The advantage of tying one's hand. EMS discipline and central bank credibility. European Economic Review 32, pp. 1055-1075. 
Modellen Österreichs. Wirtschaftspolitische Blätter $24 / 3$, pp. 80-90.

HAMADA, K. (1976): A strategic analysis of monetary independence. Journal of Political Economy 84, pp. 677-700.

HANDLER, H. (1989): Grundlagen der österreichischen Hartwährungspolitik. Manz Verlag, Wien.

HOCHREITER, E. and KNÖBL, A. (1991): Exchange Rate Policy of Austria and Finland. Two Examples of a Peg. De Pecunia 3, October, pp. 33-60.

HOCHREITER, E. and WINCKLER, G. (1991): Signaling a Hard Currency Strategy. Paper presented at the Southern California Workshop on International Political Economy: "Central Bank Independence, Fiscal Constraints, and European Monetary Union", 1991.

KAHN, G.A. (1987): International Policy Coordination in an Interdependent World. Federal Reserve Bank of Kansas City Economic Review, March, pp. 14-32.

KOOL, C.J.M. and TATOM, J.A. (1988): International Linkages in the Term Structure of Interest Rates. Federal Reserve Bank of St. Louis Review 70, July/August, pp. 30-43.

KYDLAND, F. and PRESCOTT, E. (1977): Rules rather than discretion: The inconsistency of optimal plans. Journal of Political Economy 85, pp. 473-492.

PERSSON, T. (1988): Credibility of Macroeconomic Policy. An Introduction and a Broad Survey. European Economic Review 32, pp. 519-532.

SPAHN, H.-P. (1991): Monopolistic International Policy Coordination by DM-Appreciation: An Alternative to Flexible Exchange Rates and EMS-Harmonisation. In: MATZNER, E. and STREECK, W. (1991): Beyond 
Keynesianism. The Socio-Economics of Production and Full Employment. Edward Elgar Publishing, Aldershot.

TICHY, G. (1986): Finanzpolitik im Dienste der Zahlungsbilanz. In: WEIGEL, G., LEITHNER, E., WINDISCH, R. (eds): Handbuch der österreichischen Finanzpolitik, Vienna, pp. 451-468.

VIRÉN, M. (1989): Interest Rates, Capital Movements, and Monetary Autonomy in the EFTA Countries. EFTA Occasional Paper 26, Geneva.

WEBER, A. (1991) : Reputation and Credibility in the European Monetary System. Economic Policy 6, Nr. 12, pp. 57-102.

WINCKLER, G. (1977): Zur Diskussion "Zinspolitik in Österreich". Wirtschaftspolitische Blätter.24/3, pp. 96-104. 

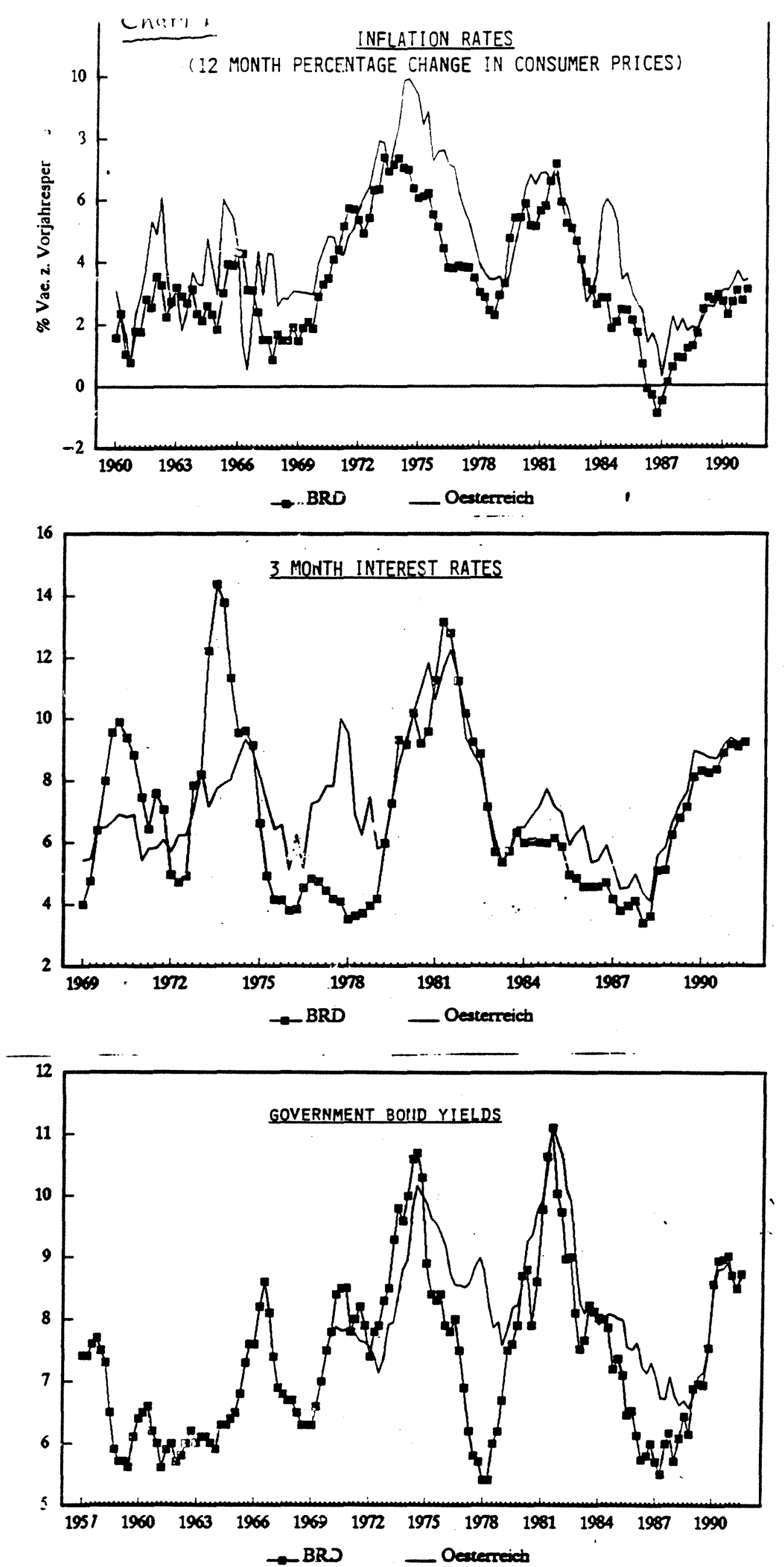
Table 1

Convergence of Fundamentals

Mean (Standard Deviation)

Austria

Germany

Inflation ( $\left.\frac{8}{8}\right)$

$\begin{array}{lll}1971-78 & 6.6(1.97) & 5.2(1.51) \\ 1979-84 & 5.2(1.42) & 4.5(1.49) \\ 1985-89 & 2.2(0.71) & 1.3(1.25)\end{array}$

Unit Labor Cost ( 8 )

$\begin{array}{lll}1971-78 & 6.1(5.21) & 5.6(3.87) \\ 1979-84 & 2.0(3.38) & 3.1(3.77) \\ 1985-89 & 0.1(2.83) & 1.5(1.71)\end{array}$

Real GDP Growth (웅

$\begin{array}{lll}1971-78 & 3.6(2.42) & 2.7(2.33) \\ 1979-84 & 2.0(1.71) & 1.6(1.73) \\ 1985-89 & 2.6(1.22) & 2.7(0.98)\end{array}$

Current Account Balance ( $\frac{8}{8}$ of GDP)

$\begin{array}{lll}1971-78 & -1.5(1.35) & 1.2(0.77) \\ 1979-84 & -0.8(1.32) & 0.1(1.22) \\ 1985-89 & -0.1(0.25) & 4.0(0.98)\end{array}$

Fiscal Deficit ( 8 of GDP)

$\begin{array}{llll}1971-78 & -2.6(1.85) & -1.4 & (1.08) \\ 1979-84 & -3.9(1.08) & -2.0(0.34) \\ 1985-89 & -4.5(0.48) & -1.2(0.36)\end{array}$

Unemployment Rate ( 8 of Labor Force)

$\begin{array}{lll}1971-78 & 1.9(0.23) & 3.0(1.71) \\ 1979-84 & 3.2(1.19) & 6.6(2.48) \\ 1985-89 & 5.2(0.30) & 8.7(0.52)\end{array}$


Table 2

Some Causality Results For Money Growth (M1)

in Austria and Germany

Period 1

( I/1960-II/1971)

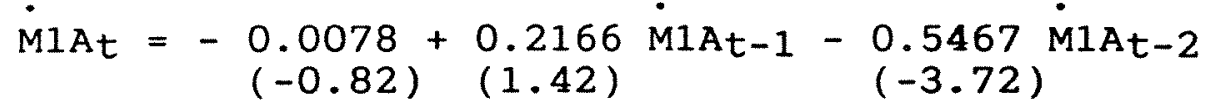

$$
\begin{aligned}
& +0.1675 \dot{\mathrm{M}} 1 \mathrm{Gt}-1+0.3855 \dot{\mathrm{M}} 1 \mathrm{Gt}-2 \\
& \text { (1.10) }(2.51) \\
& +\begin{array}{l}
0.0088 \mathrm{~S} 1 \\
(0.94)
\end{array}+\begin{array}{l}
0.0408 \mathrm{~S} 2 \\
(3.18)
\end{array}+\begin{array}{l}
0.0473 \mathrm{~S} 3 \\
(3.61)
\end{array} \\
& R^{2}=0.89 \quad \text { S.E. }=0.0093 \quad \text { D.W. }=2.00 \quad Q(10)=3.70 \\
& \dot{M i G t}=\begin{array}{l}
0.0435 \\
(13.44)
\end{array}-\begin{array}{l}
0.0750 \mathrm{~s} 1 \\
(-16.39)
\end{array}-\underset{(-1.004)}{0.0048} \mathrm{~s} 2-0.0200 \mathrm{~s} 3 \\
& R^{2}=0.885 \quad \text { S.E. }=0.0107 \quad \text { D.W. }=1.42 \quad Q(12)=9.69
\end{aligned}
$$

M1A does not cause M1G

\section{Period 2}

( II/1971-III/1979)

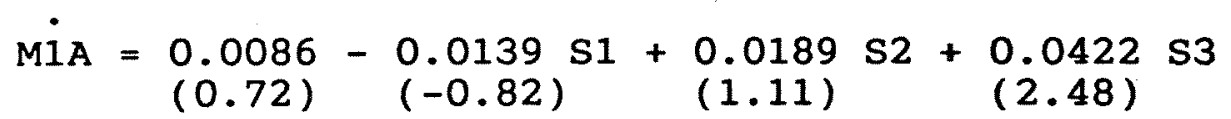

$$
\begin{aligned}
& R^{2}=0.231 \quad \text { S.E. }=0.0339 \quad \text { D.W. }=1.62 \quad Q(12)=4.97
\end{aligned}
$$

M1G does not cause M1A

$$
\begin{aligned}
& \dot{M i G}=\underset{(6.19)}{0.0437} \begin{array}{c}
0.0966 \mathrm{~s} 1 \\
(-11.24)
\end{array}+\underset{(1.02)}{0.0130 \mathrm{~s} 2}-\begin{array}{l}
0.0354 \mathrm{~s} 3 \\
(-4.31)
\end{array} \\
& +0.3918 \mathrm{MiGt-1} \\
& \text { (2.18) } \\
& R^{2}=0.851 \quad \text { S.E. }=0.0142 \quad \text { D.W. }=2.00 \quad Q(11)=8.30
\end{aligned}
$$

MIA does not cause MIG 
Period 3

(III/1979-IV/1989)

$$
\begin{aligned}
& \mathrm{M} i \mathrm{~A}=\underset{(0.07)}{0.0003}-\underset{(-5.25)}{0.0636} \mathrm{~s} 1+\underset{(6.93)}{0.0809 \mathrm{~s} 2}-0.0027 \mathrm{~s} 3 \\
& +0.6937 \text { MiGt-1 } \\
& \text { (3.48) } \\
& R^{2}=0.760 \quad \text { S.E. }=0.0158 \quad \text { D.W. }=1.53 \quad Q(12)=8.13
\end{aligned}
$$

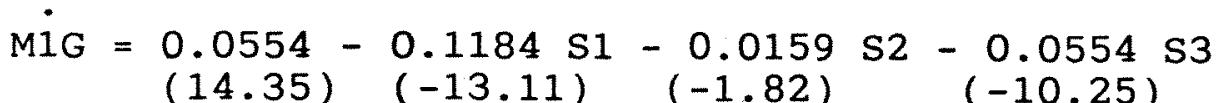

$$
\begin{aligned}
& \begin{aligned}
+ & 0.4305 \mathrm{MiGt}-1 \\
& (2.90)
\end{aligned} \\
& R^{2}=0.899 \quad \text { S.E. }=0.0118 \quad \text { D.W. }=1.99 \quad Q(11)=8.29
\end{aligned}
$$


Table 3

\section{Some Causality Results For M3 Growth in Austria and Germany}

Period 1

$$
\begin{aligned}
& \mathrm{M} \dot{3 A}=0.0030+0.0140 \mathrm{~s} 1+0.015 \mathrm{~s} 2+0.0213 \mathrm{~s} 3 \\
& \begin{array}{lll}
(0.52) \quad(3.89) \quad(5.34) \quad(8.06)
\end{array} \\
& +0.4179 \mathrm{M} \dot{3} \mathrm{At}-1 \\
& \text { (2.70) } \\
& R^{2}=0.607 \quad \text { S.E. }=0.0054 \quad \text { D.W. }=1.79 \quad Q(11)=9.22
\end{aligned}
$$

M3G does not cause M3A

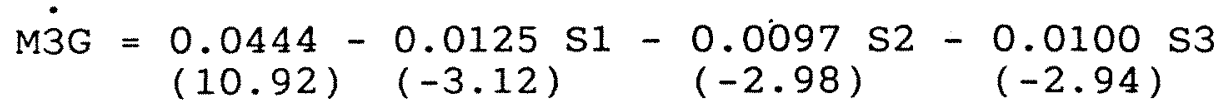

$$
\begin{aligned}
& \text { - } 0.4592 \text { M3̈Gt-5 } \\
& (-2.74) \\
& R^{2}=0.541 \quad \text { S.E. }=0.0070 \quad \text { D.W. }=1.82 \quad Q(11)=8.54
\end{aligned}
$$

M3A does not cause M3G

Period 2

$$
\begin{aligned}
& \mathrm{M} 3 \mathrm{~A}=\underset{(6.68)}{0.0401}+\underset{(2.21)}{0.0118 \mathrm{~S} 1}+\underset{(0.47)}{0.0024} \mathrm{~s} 2+\underset{(2.51)}{0.0136 \mathrm{~s} 3} \\
& -0.5065 \text { M3At-8 } \\
& (-2.75) \\
& R^{2}=0.203 \quad \text { S.E. }=0.0102 \quad \text { D.W. }=1.80 \quad Q(11)=5.12
\end{aligned}
$$

M3G does not cause M3A

$$
\begin{aligned}
& \dot{\mathrm{M} 3 \mathrm{G}}=\begin{array}{l}
0.0458 \\
(14.32)
\end{array}-\begin{array}{l}
0.0339 \mathrm{~S} 1 \\
(-7.49)
\end{array}-\begin{array}{l}
0.0290 \mathrm{~S} 2 \\
(-6.40)
\end{array}-\begin{array}{l}
0.0249 \mathrm{~s} 3 \\
(-5.49)
\end{array} \\
& \mathrm{R}^{2}=0.672 \quad \text { S.E. }=0.0091 \quad \text { D.W. }=1.75 \quad Q(12)=9.50
\end{aligned}
$$

M3A does not cause M3G 
Period 3

$$
\begin{aligned}
& \dot{\mathrm{M}} \dot{\mathrm{A}}=0.0151+0.2838 \mathrm{M} \dot{3} \mathrm{G}-1 \\
& (6.12) \quad(2.18) \\
& R^{2}=0.08 \quad \text { S.E. }=0.0102 \quad \text { D.W. }=1.58 \quad Q(12)=11.44 \\
& \dot{M} \dot{G}=0.0335-0.0241 \mathrm{~s} 1-0.0283 \mathrm{~s} 2-0.0232 \mathrm{~s} 3 \\
& \begin{array}{llll}
(20.28) & (-10.08) & (-11.81) & (-9.90)
\end{array} \\
& R^{2}=0.810 \quad \text { S.E. }=0.0055 \quad \text { D.W. }=1.70 \quad Q(12)=13.30
\end{aligned}
$$


Table 4

\section{Causality Results For The Rate of Increase of} Consumer Prices in Austria and Germany

Period 1

$$
\begin{aligned}
& \dot{\text { PAt }}=\begin{array}{c}
0.0150-0.0541 \\
(7.60)
\end{array} \text { PAt-1 }-\begin{array}{l}
0.6487 \text { PAt }-2 \\
(-0.46)
\end{array} \\
& R^{2}=0.401 \quad \text { S.E. }=0.0085 \quad \text { D.W. }=2.10 \quad Q(12)=9.43
\end{aligned}
$$

PG does not cause PA

$$
\begin{aligned}
& \dot{P} G_{t}=\underset{(0.33)}{0.0012}+\underset{(1.01)}{0.1570} \dot{P} G_{t-1}-\underset{(-3.45)}{0.5868} \dot{P}_{t-2}+\underset{(0.05)}{0.0060} \dot{P A A t}_{t-1}
\end{aligned}
$$

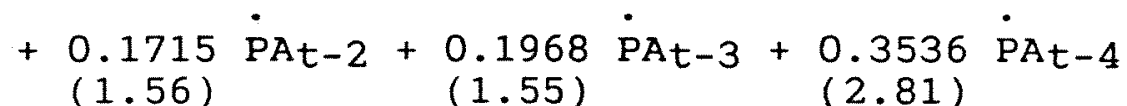

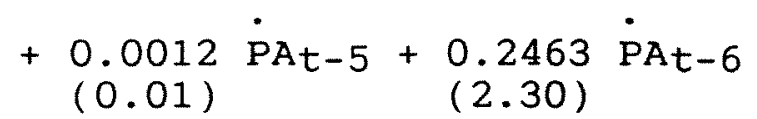

$$
\begin{aligned}
& R^{2}=0.423 \quad \text { S.E. }=0.0053 \quad \text { D.W. }=1.84 \quad Q(9)=7.93
\end{aligned}
$$

PA causes $\dot{P G}: F 6,34=2.92$, critical value $=2.49$

Period 2:

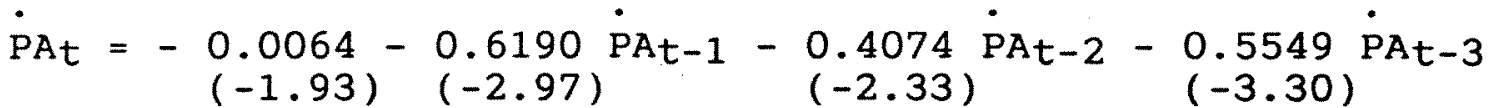

$$
\begin{aligned}
& +0.4247 \dot{\mathrm{PG}} \mathrm{t}-1+0.1919 \dot{\mathrm{PG}} \mathrm{t}-2+0.2200 \dot{\mathrm{PG}} \mathrm{t}-3
\end{aligned}
$$

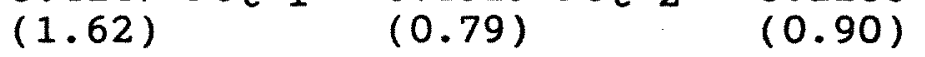

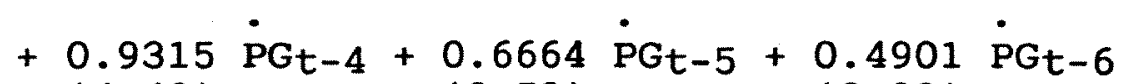

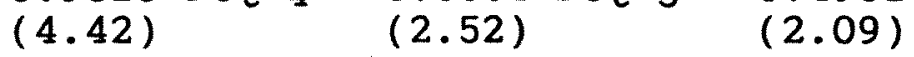

$$
\begin{aligned}
& +0.8077 \dot{\mathrm{PG}}-7 \\
& \text { (3.00) } \\
& R^{2}=0.649 \quad \text { S.E. }=0.0042 \quad \text { D.W. }=1.87 \quad Q(9)=5.96 \\
& \dot{P G} \text { causes } \dot{P A}: F 7,21=7.87 ; \text { critical value }=2.49
\end{aligned}
$$




$$
\begin{aligned}
& \dot{P} G_{t}=\underset{(0.35)}{0.0009}+\underset{((2.02)}{0.3177} \dot{P}_{t-1}-\underset{(-1.52)}{0.2481} \dot{P}_{G t-2}+\underset{(1.42)}{0.2334} \dot{P}_{G t-3} \\
& +0.5897 \dot{P} G_{t-4} \\
& \text { (3.65) } \\
& R^{2}=0.598 \quad \text { S.E. }=0.0040 \quad \text { D.W. }=1.84 \quad Q(8)=5.16 \\
& \dot{\mathrm{PA}} \text { does not cause } \dot{\mathrm{PG}}
\end{aligned}
$$

\section{Period 3}

$$
\begin{aligned}
& \dot{P A t}=\underset{(1.42)}{0.0030}-\underset{(-1.05)}{0.1621} \dot{P A t-1}+\underset{(0.37)}{0.0475} \dot{P A t}-2-\underset{(-0.94)}{0.1183} \text { PAt-3 } \\
& +0.4713 \dot{\mathrm{PAt}}_{\mathrm{t}-4}+0.5570 \dot{\mathrm{PG}}_{\mathrm{t}-1} \\
& \text { (3.48) (2.77) } \\
& R^{2}=0.457 \quad \text { S.E. }=0.0060 \quad \text { D.W. }=1.72 \quad Q(8)=8.51 \\
& \dot{P} G_{t}=\underset{(1.04)}{0.0012}+\underset{(5.13)}{0.7010} \dot{P}_{t-1}-\underset{(-2.54)}{0.4016} \dot{P}_{t-2}+\underset{(4.00)}{0.5155} \dot{P}_{t-3} \\
& R^{2}=0.540 \quad \text { S.E. }=0.0044 \quad \text { D.W. }=2.18 \quad Q(9)=2.63 \\
& \dot{\mathrm{PA}} \text { does not cause } \dot{\mathrm{PG}}
\end{aligned}
$$


Table 5

Causality Results For Industrial Production

Growth in Austria and Germany

Period 1

$$
\begin{aligned}
& \Delta L I P A=\underset{(2.52)}{0.0120}-\underset{(-3.47)}{0.4884} \Delta \text { LIPAt }-1+\underset{(2.40)}{0.4135} \Delta \text { LIPGt }-1 \\
& \begin{aligned}
+ & 0.1879 \text { औLIPGt }-2+ \\
(1.15) & 0.3570 \wedge L I P G t-3
\end{aligned} \\
& R^{2}=0.261 \quad \text { S.E. }=0.0214 \quad \text { D.W. }=1.68 \quad Q(11)=7.94
\end{aligned}
$$

IPG causes IPA

$$
\begin{aligned}
\triangle L I P G= & 0.0124 \\
& (4.11) \\
& R^{2}=0.0 \quad \text { S.E. }=0.0203 \quad \text { D.W. }=1.75 \quad Q(12)=13.41
\end{aligned}
$$

IPA does not cause IPG

Period 2

$$
\begin{aligned}
\Delta L I P A & =\begin{array}{l}
0.0055 \\
(1.57)
\end{array} \\
& R^{2}=0.2875 \Delta L I P G t-1+\underset{(1.42)}{0}=0.4390 \Delta L I P G t-2 \\
(2.15) & \text { S.E. }=0.0192 \quad \text { D.W. }=2.54 \quad Q(12)=6.67
\end{aligned}
$$

IPG causes IPA : F 5,26=3.53; critical value $=2.64$

$$
\begin{aligned}
& \Delta L I P G=\underset{(1.70)}{0.0053}+\underset{(2.11)}{0.3747} \text { \LIPGt-1 }-\underset{(-0.66)}{0.1287} \text { \&LIPGt-2 }
\end{aligned}
$$

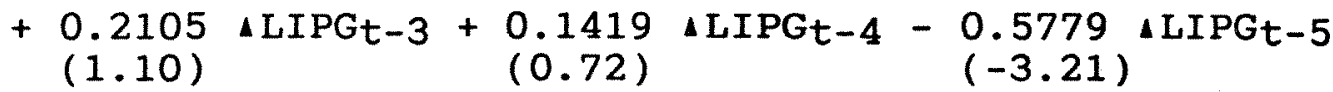

$$
\begin{aligned}
& R^{2}=0.290 \quad \text { S.E. }=0.0165 \quad \text { D.W. }=1.68 \quad Q(7)=4.33
\end{aligned}
$$

IPA does not cause IPG 
Period 3

$$
\begin{aligned}
& \triangle L I P A_{t}=0.0056+0.3164 \Delta L I P G_{t-1} \\
& (2.31) \quad(2.36) \\
& \mathrm{R}^{2}=0.10 \quad \text { S.E. }=0.0153 \quad \text { D.W. }=2.07 \quad Q(12)=15.03 \\
& \Delta \text { LIPAT }=0.0031+0.3377 \text { ALPAT }-5+0.3617 \text { ALIPGt }-1 \\
& \begin{array}{lll}
(1.24) \quad(2.42) \quad(2.82)
\end{array} \\
& \mathrm{R}^{2}=0.197 \quad \text { S.E. }=0.0145 \quad \text { D.W. }=2.02 \quad Q(11)=9.10 \\
& \text { IPG causes IPA }
\end{aligned}
$$

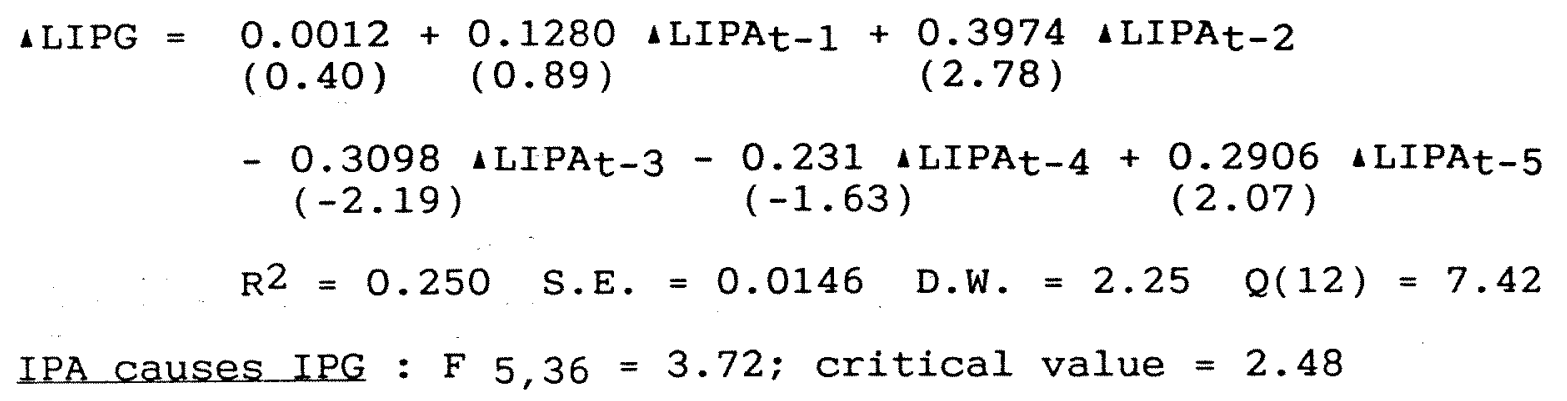


Table 6

\section{Causality Results For Long-term Interest Rates \\ in Austria and Germany}

Period 2

$$
\begin{aligned}
\Delta I L A= & \begin{array}{l}
0.0124 \\
(0.27)
\end{array} \\
& R=\underset{(2.48)}{R}=0.3864 \Delta I L A t-1+\underset{(2.40)}{0.2384} \Delta I L G t-1 \\
&
\end{aligned}
$$

ILG causes ILA

$$
\begin{aligned}
\Delta I L G= & \begin{array}{ll}
0.0022+0.5183 \wedge I L G t-1 \\
(0.03) \\
\end{array} \\
& R^{2}=0.221 \quad \text { S.E. }=0.4353 \quad \text { D.W. }=1.85 \quad Q(12)=7.58
\end{aligned}
$$

ILA does not cause ILG

Period 3

$$
\begin{aligned}
\Delta I L A=- & \underset{(-0.011}{(-0.02)}+\underset{(2.09)}{0.2746} \Delta I L A t-3+\underset{(3.84)}{0.3298} \Delta I L G t-1 \\
& R^{2}=0.316 \mathrm{~S} . E .=0.2858 \quad \mathrm{D} . W .=2.06 \quad Q(11)=8.26
\end{aligned}
$$

ILG causes ILA

$$
\begin{aligned}
& \Delta I L G t=\underset{(0.01)}{0.0007}+\underset{(2.92)}{0.6367} \Delta \text { ILGt-1 }-\underset{(-2.61)}{0.9463} \Delta \text { ILAt-1 } \\
& +0.625 \text { IILAt }-2 \\
& \text { (2.31) } \\
& \mathrm{R}^{2}=0.138 \quad \text { S.E. }=0.478 \quad \text { D.W. }=1.90 \quad \mathrm{Q}(11)=7.97
\end{aligned}
$$

ILA causes ILG 
Table 7

Causality Results For Short-term Interest Rates

in Austria and Germany

Period 1

$$
\begin{aligned}
& \Delta I S A t=\underset{(2.25)}{0.2798}+\underset{(0.28)}{0.0307} \text { iISGt-1 }-\underset{(-0.50)}{0.0563} \text { iISGt-2 }
\end{aligned}
$$

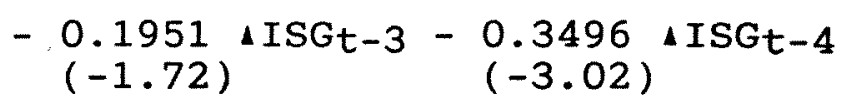

$$
\begin{aligned}
& \mathrm{R}^{2}=0.182 \quad \text { S.E. }=0.7227 \quad \text { D.W. }=2.43 \quad Q(8)=12.17 \\
& \triangle \text { ISGt }=0.1431 \\
& (0.94) \\
& \mathrm{R}^{2}=0.00 \quad \text { S.E. }=1.0176 \quad \text { D.W. }=1.87 \quad Q(12)=17.01 \\
& \triangle I S G=0.2448-0.3503 \wedge \text { ISGt }-5 \\
& (1.46) \quad(-3.26) \\
& R^{2}=0.086 \quad \text { S.E. }=1.0319 \text { D.W. }=1.89 \quad Q(11)=9.40
\end{aligned}
$$

ISA does not cause ISG

Period 2

$$
\begin{aligned}
\Delta I S A=- & 0.0417 \\
& (-0.19) \\
& R^{2}=0.00 \quad \text { S.E. }=1.1411 \quad \text { D.W. }=2.36 \quad Q(12)=6.36
\end{aligned}
$$

ISG does not cause ISA

$$
\begin{aligned}
& \Delta \text { ISG }=\begin{array}{l}
0.0277+0.4094 \Delta I S G t-1 \\
(0.12)(2.40)
\end{array} \\
& R^{2}=0.133 \quad \text { S.E. }=1.2929 \quad \text { D.W. }=1.79 \quad \mathrm{Q}(11)=7.05
\end{aligned}
$$

ISA does not cause ISG 
Period 3

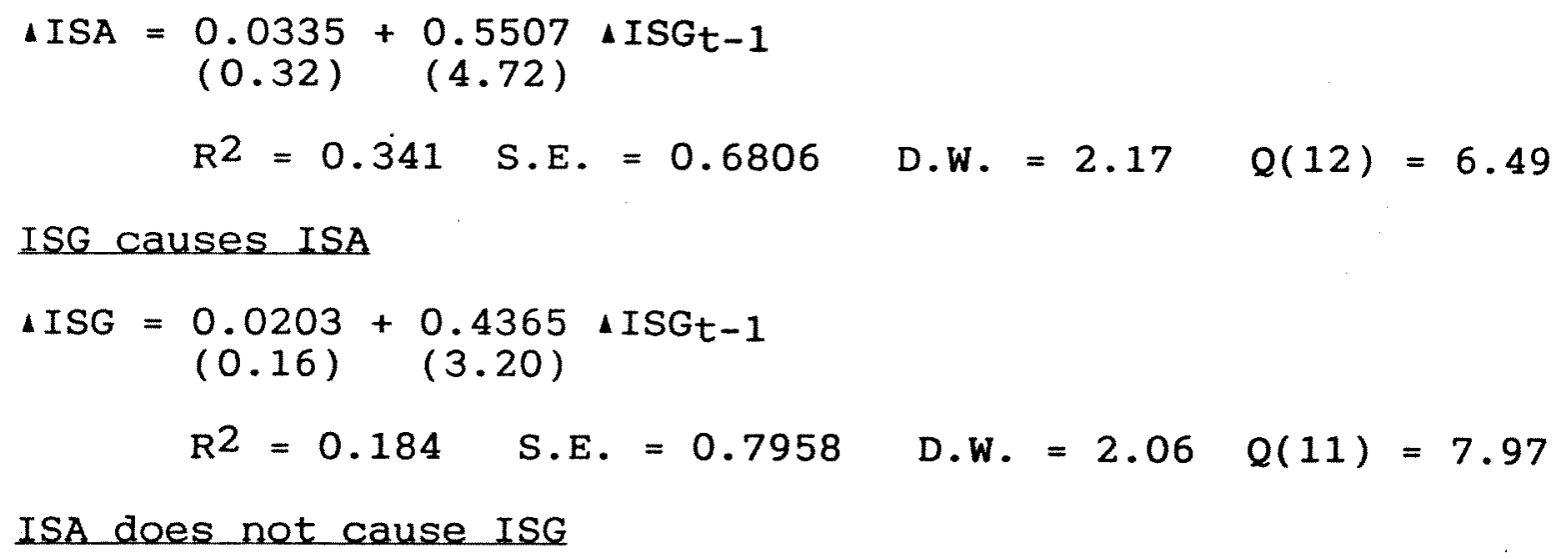


Table 8

\section{Cointegration Vectors For Inflation}

$I / 1960-I I / 1971$

$$
\begin{aligned}
& \triangle L P A=0.006+0.451 \triangle L P G+R 1 \\
& (2.61) \quad(1.89) \\
& \mathrm{R}^{2}=0.05 \quad \text { S.E. }=0.0106 \quad \text { D.W. }=2.05 \\
& \triangle \mathrm{R} 1=-1.711 \mathrm{R} 1_{t-1}+0.651 \mathrm{LR} 1_{t-1} \\
& (-10.00) \quad(5.47) \\
& R^{2}=0.709 \quad \text { S.E. }=0.0082 \quad \text { D.W. }=2.14
\end{aligned}
$$

\section{III/1971 - II/1979:}

$$
\begin{aligned}
& \triangle \mathrm{LPA}=0.007+0.757 \triangle \mathrm{LPG}+\mathrm{R} 2 \\
& (3.16) \quad(4.94) \\
& R^{2}=0.43 \quad \text { S.E. }=0.0054 \quad \text { D.W. }=1.61 \\
& \Delta R 2=\frac{-0.931 \mathrm{R} 2 \mathrm{t}-1}{(-4.87)} \\
& \begin{array}{lll}
R^{2}=0.43 & \text { S.E. }=0.0053 & \text { D.W. }=1.76
\end{array}
\end{aligned}
$$

III/1979 - II/1991:

$$
\begin{aligned}
& \triangle \mathrm{LPA}=0.0043+0.688 \Delta \mathrm{LPG}+\mathrm{R} 3 \\
& R^{2}=0.27 \quad \text { S.E. }=0.0067 \quad \text { D.W. }=2.63 \\
& \Delta R 3=\underset{(-9.41)}{-0.864} R 3 t-1+\underset{(2.52)}{0.278} \Delta R 3 t-4+\underset{(2.39)}{0.286} \Delta R 3 t-8 \\
& \mathrm{R}^{2}=0.79 \quad \text { S.E. }=0.0053 \quad \text { D.W. }=2.17
\end{aligned}
$$



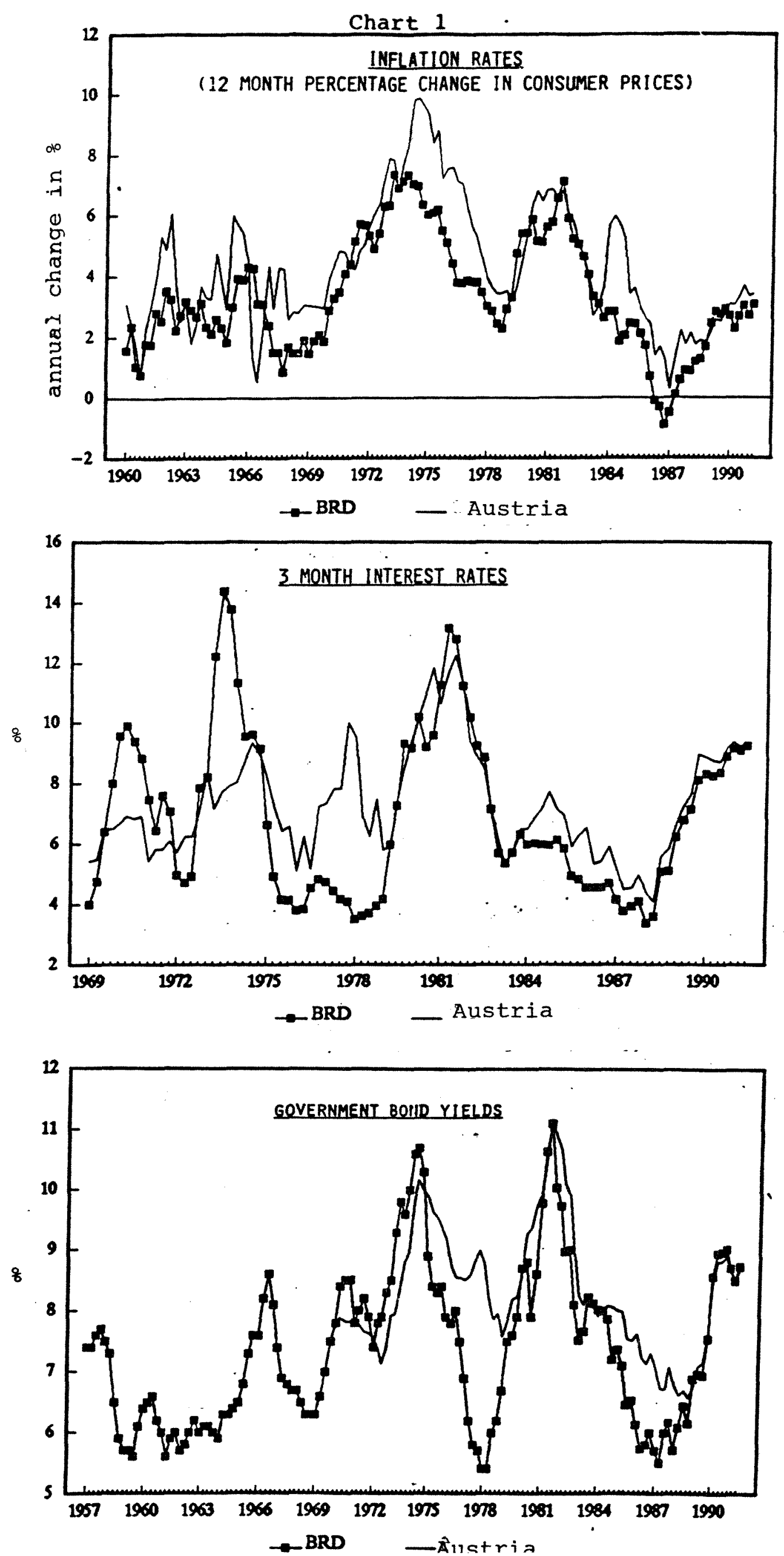